\title{
Crawling Data Customer Pada Aplikasi Smarsofi Untuk Layanan Digital Marketing
}

\author{
Ahmad Maulana ${ }^{1}$, Erika Devi Udayanti ${ }^{2}$, Yusuf Yudha Sanjaya ${ }^{3}$, Rifky Anggadiva ${ }^{4}$, Maulana \\ Muhammadin Comara ${ }^{5}$, Mohamad Sirojul Muna ${ }^{6}$ \\ ${ }^{1}$ Fakultas IImu Komputer Universitas Dian Nuswantoro \\ Semarang, (024)3575916, e-mail: ahmadmaulana4040@gmail.com \\ 2 Fakultas Ilmu Komputer Universitas Dian Nuswantoro \\ Semarang, (024)3575916, e-mail: erikadevi@dsn.dinus.ac.id \\ ${ }^{3}$ Fakultas IImu Komputer Universitas Dian Nuswantoro \\ Semarang, (024)3575916, e-mail: yusufsanjaya@gmail.com \\ ${ }^{4}$ Fakultas IImu Komputer Universitas Dian Nuswantoro \\ Semarang, (024)3575916, e-mail: rifkyprasetya18@gmail.com \\ ${ }^{5}$ Fakultas IImu Komputer Universitas Dian Nuswantoro \\ Semarang, (024)3575916, e-mail: adincomara@gmail.com \\ ${ }^{6}$ Fakultas Ilmu Komputer Universitas Dian Nuswantoro \\ Semarang, (024)3575916, e-mail: sirojulmuna@gmail.com
}

\section{ARTICLE INFO}

Article history:

Received : 22 Juny 2019

Received in revised form : 29 July 2019

Accepted : 25 july 2019

Available online : 31 July 2019

\begin{abstract}
Current communication can be done without having to be face to face, without limitation of space and time, namely through the internet. The growth of internet users affects the changing patterns of society in communicating and socializing which also impacts on business trends, one of which is on the aspects of promotion and marketing. Conventional promotion through print media has shifted to online media with the approach of digital marketing promotion or digital marketing. In the promotion effort, source data is needed, namely the identity of the target customer, so that customer data is needed. This research will discuss the extraction of customer data developed in a software, Smarsofi. by crawling data users who use a WiFi internet connection, brief information is obtained regarding the customer. Testing the functionality of the smarsofi application is done by the blackbox testing method. the results obtained from this study are software that can support digital marketing services.
\end{abstract}

Keywords: smarsofi, social wifi, digital marketing

\section{Pendahuluan}

Kemajuan teknologi membawa perubahan pada pola komunikasi dan interaksi masyarakat maupun aktivitas bisnis. Komunikasi 2 arah saat ini dapat dilakukan tanpa harus bertatap muka langsung, tanpa batasan ruang dan waktu yaitu melalui internet. Kini ketersediaan konektivitas internet menjadi kebutuhan bagi seluruh masyarakat dalam hampir keseluruhan aktivitas seharihari, mulai dari berkomunikasi, berbelanja, belajar, transaksi keuangan, maupun aktivitas sosial.

Received Juni 22, 2019; Revised July 29, 2019; Accepted July 25, 2019 
Dari hasil survei yang dilakukan oleh APJII, hingga tahun 2017 penetrasi pengguna internet terus mengalami peningkatan. Ada sejumlah 54,68\% dari keseluruhan populasi penduduk Indonesia yaitu mencapai 143,26 juta jiwa adalah pengguna internet. Jumlah ini mengalami peningkatan dimana yang pada tahun sebelumnya pengguna internet mencapai 132,7 juta jiwa. Hal ini nampak seperti yang ditunjukkan dalam grafik pertumbuhan pengguna internet pasa Gambar 1.

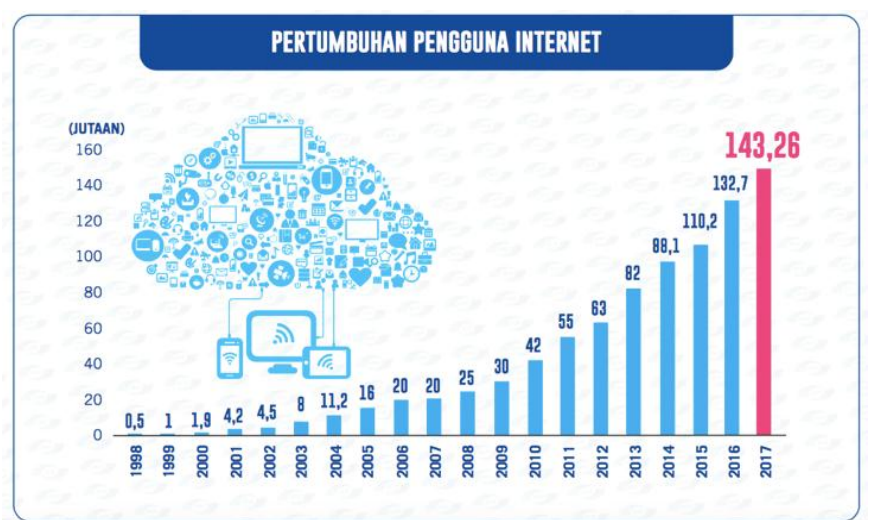

Gambar 1. Pertumbuhan pengguna internet di Indonesia [1]

Sedangkan pada tahun 2018, jumlah pengguna internet mengalami kenaikan hingga 10,12\%. Jumlah ini cukup banyak hingga mencapai 27,9 juta pengguna internet baru di tahun 2018 yang tentunya tersebar di berbagai wilayah Indonesia. Dari jumlah tersebut, pengguna internet didominasi oleh pengguna usia produktif yaitu usia remaja dan dewasa dengan rentan usia 19 hingga 50 tahun seperti pada Gambar 2 [2]. Untuk mengakses internet, masyarakat lebih banyak menggunakan perangkat mobile seperti smartphone, tablet, maupun laptop yang kemudian terhubung ke penyedia layanan internet. Penggunaan jaringan wireless ini sangat mendominasi di berbagai keperluan, baik keperluan pribadi maupun keperluan bisnis. Sehingga banyak ruang publik atau fasilitas umum yang dilengkapi dengan hotspot area untuk akses free wifi. Bahkan setiap kantor, gedung, dan restoran hingga angkringan pun saat ini juga harus menyediakan akses free wifi bagi karyawan maupun pengunjung. Jaringan wireless merupakan komunikasi antara 2 perangkat atau lebih dalam teknologi jaringan tanpa menggunakan kabel [3]. Setiap pengguna dapat terhubung ke internet dengan melakukan login menggunakan suatu akun yang sudah disediakan ataupun dengan mendaftarkan diri terlebih dahulu.

Pengguna internet berdasarkan umur tahun 2018

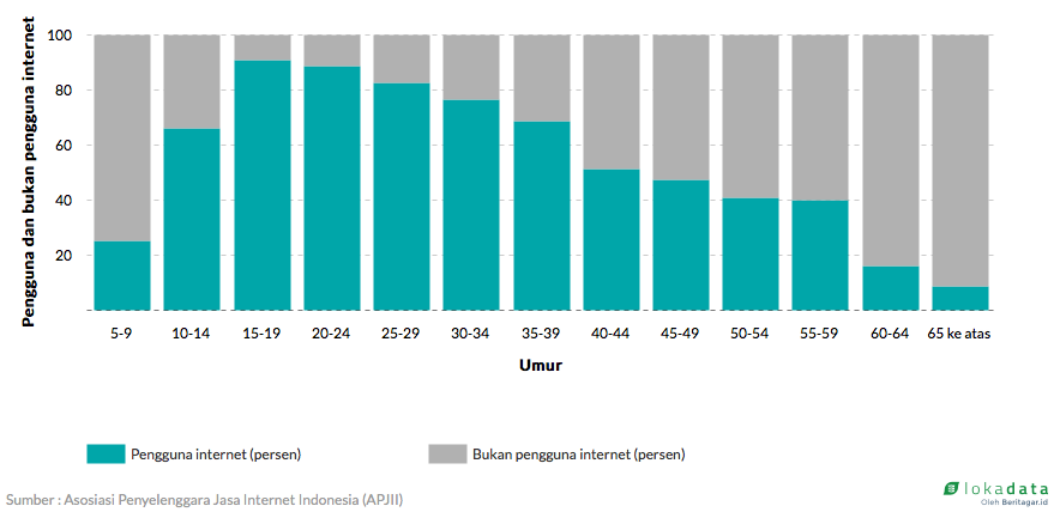

Gambar 2. Pertumbuhan Pengguna internet berdasarkan usia [2]

Pertumbuhan pengguna internet yang kemudian mempengaruhi perubahan pola masyarakat dalam berkomunikasi dan berinteraksi yang tentunya juga berdampak pada tren bisnis, salah satunya yaitu pada aspek promosi dan pemasaran [4]. Promosi konvensional melalui media TRANSFORMATIKA Vol. 17, No. 1, July 2019: 41-48 
cetak sudah beralih ke media online. Media- media cetak beralih ke dalam bentuk digital yang kemudian disebarluaskan dengan sangat mudah melalui internet ke banyak masyarakat luas. Pendekatan promosi pemasaran digital atau digital marketing yang merupakan aktivitas pengenalan bisnis (produk) dan eksplorasi pasar yang dilakukan dengan media digital secara online melalui berbagai beragam media. Digital marketing yang merupakan suatu proses dari aktivitas dengan memanfaatkan teknologi digital untuk upaya penciptaan, komunikasi, serta penyampaian suatu nilai kepada para konsumen maupun pihak- pihak lain yang terkait [5]. Bahkan aktivitas pemasaran yang dilakukan dengan memanfaatkan internet juga didefinisikan sebagai digital marketing [6].

Dalam usaha promosi tentu diperlukan sumber data yaitu identitas target customer, sehingga diperlukan crawling data customer. Hal ini dilakukan pada media sosial diantaranya twitter, facebook, instagram, dan media sosial lain. Pada beberapa penelitian, pengembangan aplikasi crawling data ditujukan untuk membangun web crawler guna menghimpun informasi yang tersebar di internet yaitu media sosial. Diantaranya yaitu pengembangan web crawler yang memanfaatkan text mining dalam mengumpulkan tweet [7]. Pada penelitian berikutnya, yaitu pengambilan data twitter untuk menemukan kurator suatu berita melalui pengumpulan data pengguna twitter dan data tweet yang ada [8]. Bagaimanapun crawling data pada media sosial untuk mendapatkan data customer tidak praktis karena memerlukan kemampuan ahli, metode khusus seperti data mining ataupun text mining, ataupun bahkan aplikasi khusus, sehingga cukup mahal bagi bisnis berskala kecil.

Penelitian ini akan membahas crawling data customer untuk area terbatas. Konsep crawling data yang diusulkan ini dikembangkan dalam sebuah perangkat lunak yaitu Smarsofi atau smart social wifi. Hasil yang diperoleh melalui ekstraksi data user yang menggunakan koneksi internet wifi yaitu informasi singkat terkait customer, dalam hal ini aplikasi smarsofi diterapkan pada sebuah cafe. Tujuan utamanya adalah untuk memudahkan proses pengumpulan data pengunjung café yang terkoneksi ke wifi yang selanjutnya akan diteruskan untuk distribusi (broadcast) pesan promosi secara digital. Aplikasi smarsofi ini cocok digunakan sebagai layanan digital marketing khususnya bagi bisnis skala kecil menengah. Pengujian aplikasi smarsofi dilakukan dengan menggunakan metode blackbox testing guna menguji fungsionalitas masing- masing fitur yang ada.

\section{Metodologi}

Penelitian ini menggunakan pendekatan penelitian rekayasa yang mana masuk dalam kategori penelitian ilmu komputer [9]. Adapun tahapan utama dalam penelitian ini yaitu penyiapan data yang diperlukan dan pembuatan sistem atau perangkat lunak. Pada tahapan pembuatan sistem mengacu pada model pengembangan sistem waterfall.

\subsection{Penyiapan Data}

Penelitian ini mengumpulkan data melalui wawancara langsung dengan target pengguna sistem (end user) nantinya. Hal ini dilakukan untuk memperoleh data primer penelitian yang terdiri dari kebutuhan sistem maupun kebutuhan pengguna sistem. Data ini didukung dengan data sekunder yang diperoleh dari berbagai sumber pustaka.

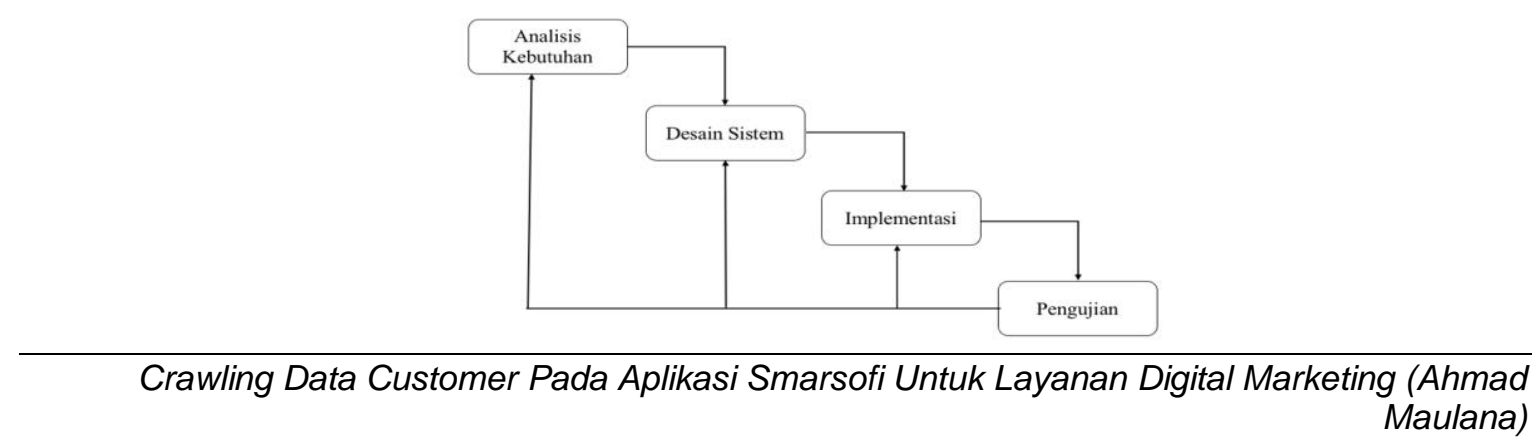


Gambar 3. Metodologi Pengembangan Sistem Model Waterfall [10]

\subsection{Pembuatan Sistem}

Digambarkan tahapan pengembangan sistem dengan model waterfall dalam Gambar 2 [10]. Tahapan pembuatan sistem dimulai dengan aktivitas analisis kebutuhan sistem yaitu kebutuhan layanan oleh pengguna sistem. Tahapan berikutnya yaitu membuat rancangan sistem sesuai pada kebutuhan sistem yang telah didefiniskan sebelumnya. Kemudian desain akan diimplementasikan dalam suatu bahasa pemrograman untuk setiap unit atau fungsionalitas sistem dan dilakukan integrasi setiap fungsionalitas sistem.

\section{Hasil}

Berikut ini akan dipaparkan hasil yang diperoleh dalam pengembangan aplikasi smarsofi dengan merujuk pada aktivitas dalam metodologi pengembangan sistem.

\subsection{Analisis Kebutuhan Sistem}

Kebutuhan pengguna dianalisis untuk mendapatkan gambaran dari fungsionalitas sistem yang diperlukan sesuai dengan spesifikasi pengguna. Kebutuhan pengguna selanjutnya dikelompokkan ke dalam kebutuhan fungsional (functional requirement) dan non fungsional (nonfunctional requirement) sistem. Dalam hal kebutuhan fungsional sistem dari smarsofi yang dikembangkan adalah ditunjukkan dalam Gambar 3. Pengguna sistem terdiri dari admin sistem dan end user (pengguna) yaitu pengunjung café.

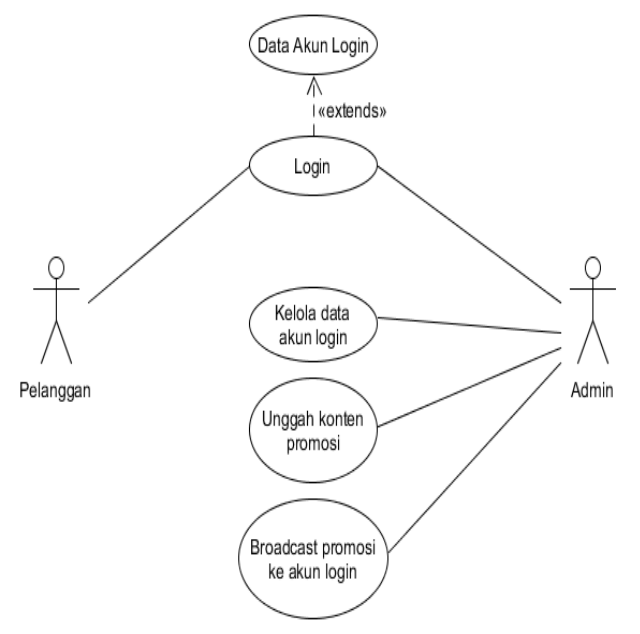

Gambar 4. Use case diagram sistem smarsofi

Admin sistem sebagai pengelola utama untuk konektivitas wifi dan juga pengelola utama dari seluruh data yang ada. Fitur login diberikan untuk admin sebelum dapat mengelola data maupun distribusi pesan promosi. Sedangkan fitur login untuk end user adalah untuk layanan konektivitas ke wifi dimana setiap end user dapat terkoneksi ke wifi dengan memasukkan akun sosial media yaitu twitter, facebook, dan google. Dari data pengguna wifi inilah yang kemudian dikumpulkan dan diproses sebagai penerima layanan promosi digital.

Tabel 1. Kebutuhan Non Fungsional Smarsofi

\begin{tabular}{cl}
\hline Jenis & \multicolumn{1}{c}{ Penjelasan } \\
\hline Platform OS & 1. Dapat diakses dalam multiplatform OS \\
& 2. Framework pengembangan yaitu laravel \\
& 3. OS client : multiplatform \\
\hline
\end{tabular}

TRANSFORMATIKA Vol. 17, No. 1, July 2019: 41-48 


\section{Maksimum client: 50}
Performansi 1. Broadcast promosi maksimal ke 50 akun media sosial dalam 1 kali distribusi.
2. Auto checking untuk akun

Data Setiap akun pengguna wifi yang telah tersimpan tidak akan disimpan ulang.

Keamanan Admin dan end user memiliki hak akses yang berbeda

Piranti Versi Mikrotik : 750GR3

Mikrotik

Sedangkan kebutuhan non fungsional sistem dari smarsofi ditinjau dari beberapa kategori yaitu kebutuhan platform sistem operasi untuk lingkungan pengembang maupun pengguna, performansi, data, dan juga keamanan sistem. Tabel 1 menjelaskan setiap kebutuhan non fungsional tersebut.

\subsection{Desain Arsitektur Sistem}

Aplikasi smarsofi yang dikembangkan didasarkan pada desain arsitektur mikrotik yaitu topologi mikrotik hotspot seperti yang ditunjukkan pada Gambar 4. Mikrotik terhubung ke wireless yang kemudian memberikan layanan ke setiap user atau client. Masing- masing client dapat terhubung ke internet baik menggunakan perangkat smatphone, tablet, maupun laptop. Dari setiap client yang meminta layanan internet melalui login wifi dengan menginputkan akun media sosial, selanjutnya dari server hosting akan diproses untuk dapat dilakukan crawling data client tersebut. Dari hasil crawling yang dilakukan melalui graph api, selanjutnya data yang terkumpul akan disimpan untuk dapat digunakan sebagai bahan atau sumber target pelanggan dalam promosi. Aplikasi smarsofi akan melakukan penyebaran konten promosi ke data target kustomer yang telah dikumpulkan tersebut.

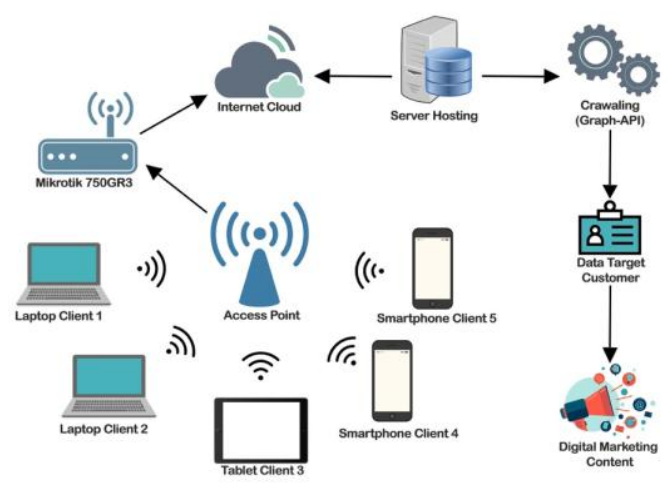

Gambar 5. Arsitektur Smarsofi

\subsection{Hasil Pengembangan Sistem}

Sesuai kebutuhan fungsional dan non fungsional dari aplikasi smarsofi serta arsitektur aplikasi, selanjutnya dibangun dalam 2 platform atau versi yaitu aplikasi untuk pelanggam dan

Crawling Data Customer Pada Aplikasi Smarsofi Untuk Layanan Digital Marketing (Ahmad 
admin. Dimana dalam platform yang pertama bagi admin aplikasi smarsofi ini dibangun berbasis web, sedangkan bagi pelanggan dibangun berbasis mobile dan web. Berikut ini user interface dari aplikasi smarsofi yang dikembangkan.

1. Antarmuka Login Pelanggan

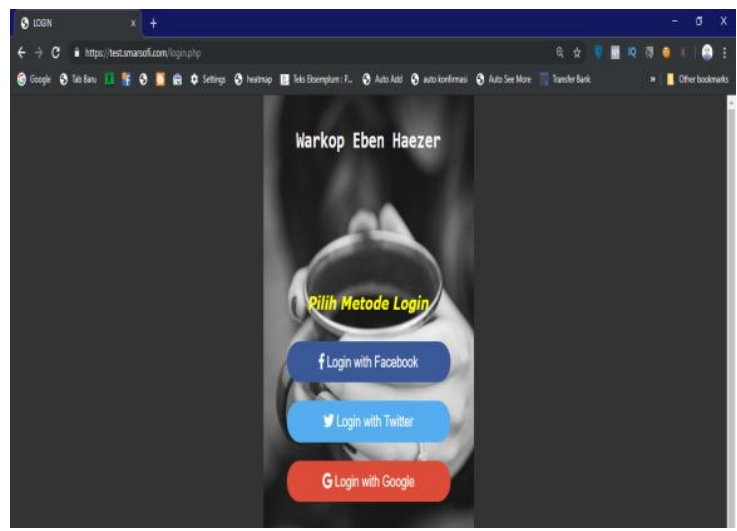

Gambar 6. Antarmuka Login User

2. Antarmuka Login Admin

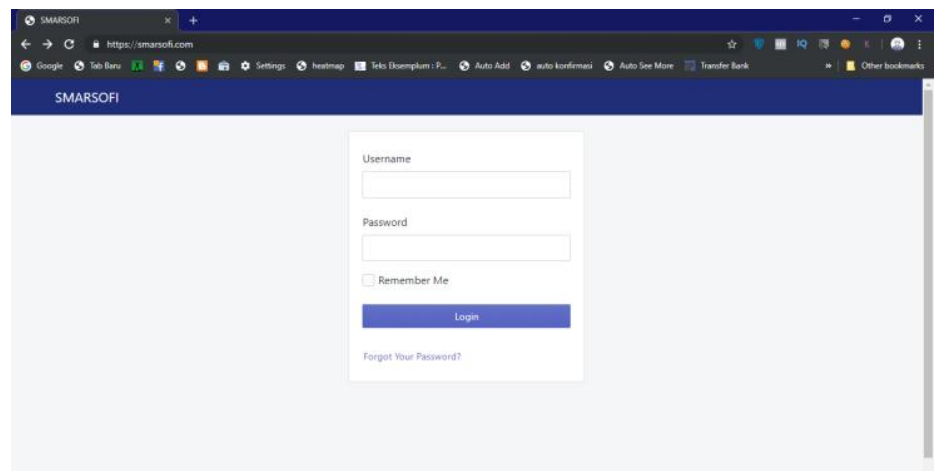

Gambar 7. Antarmuka Login Admin

3. Antamuka Crawling Data

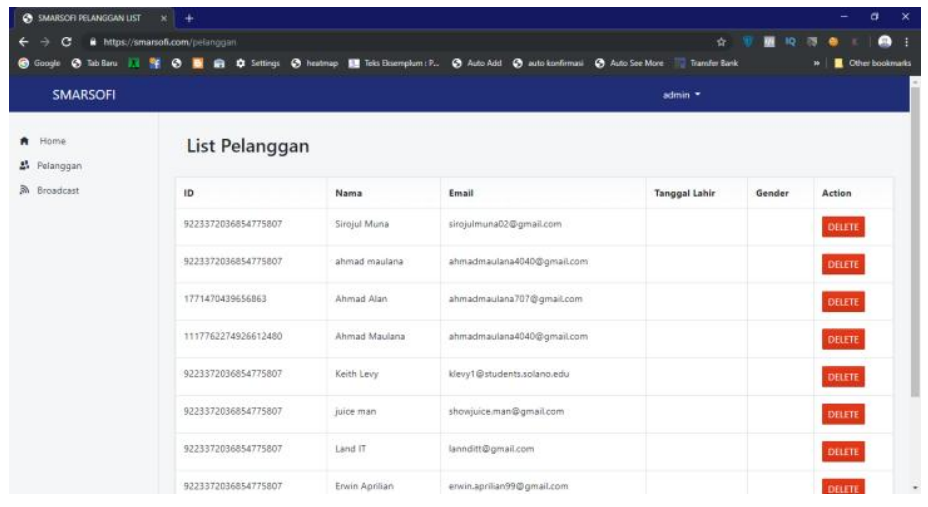

Gambar 8. Antarmuka Hasil Crawling dari Graph API

4. Antarmuka Broadcast Konten Promosi

TRANSFORMATIKA Vol. 17, No. 1, July 2019: 41 - 48 


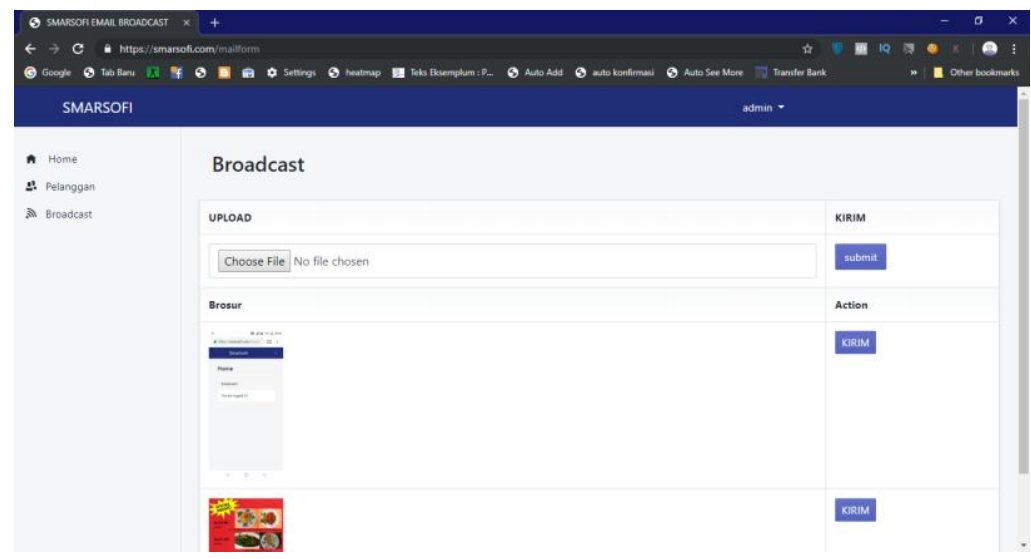

Gambar 9. Antarmuka Broadcast Pesan Promosi

\subsection{Uji Fungsionalitas Sistem}

Pengujian sistem dilakukan dengan metode black box yaitu melakukan pengujian terhadap fungsionalitas sistem. Uji fungsionalitas dilakukan dengan memberikan test case untuk masingmasing fitur.

Tabel 2. Hasil Uji Fungsionalitas Smarsofi

\begin{tabular}{clc}
\hline No & \multicolumn{1}{c}{ Test Case } & Hasil \\
\hline 1 & Akses aplikasi versi mobile & Berhasil \\
\hline 2 & Akses aplikasi versi web & Berhasil \\
\hline 3 & Login wifi oleh pengguna & Berhasil \\
\hline & 1. Format akun benar & Berhasil \\
\hline & 2. Format akun salah & Berhasil \\
\hline 4 & Login aplikasi oleh admin & Berhasil \\
\hline & 1. Kombinasi username dan password benar \\
& $\begin{array}{l}\text { 2. Kombinasi username benar dan password } \\
\text { salah }\end{array}$ & Berhasil \\
\hline & $\begin{array}{l}\text { 3. Kombinasi username salah dan password } \\
\text { benar }\end{array}$ & Berhasil \\
\hline 5 & Akses fitur crawling data & Berhasil \\
\hline 6 & Akses fitur konten promosi & Berhasil
\end{tabular}

\section{Kesimpulan}

Aplikasi smart social wifi atau smarsofi telah berhasil dikembangkan serta diuji coba dan diimplementasikan di lingkungan pengguna. Untuk setiap fitur yang ada dapat berfungsi dengan baik tanpa ada kendala dimana sebelumnya telah diuji terlebih dahulu. Pembaharuan layanan digital marketing disajikan dalam aplikasi smarsofi yang dapat mengumpulkan target- target promosi dan melakukan distribusi promosi. Sebagai pengembangan selanjutnya terhadap aplikasi smarsofi, dapat dikembangkan dengan memberikan pilihan login koneksi wifi melalui akun media sosial yang lain. 


\section{Acknowledgment}

Penelitian ini merupakan hasil dari implementasi untuk Program Kreativitas Mahasiswa (PKM) Penerapan Teknologi yang didanai oleh Kementrian Riset, Teknologi, dan Pendidikan Tinggi melalui Direktorat Jendral Belmawa tahun anggaran 2019.

\section{Referensi}

[1] Asosiasi Penyelenggara Jasa Internet, "Penetrasi \& Perilaku Pengguna Internet Indonesia Survey 2017," Teknopreneur, vol. 2018, no. 31 August 2018, p. Hasil Survey, 2018.

[2] Lokadata, "Pengguna Internet Berdasarkan Umur Tahun 2018," lokadata. [Online]. Available: https://lokadata.beritagar.id/chart/preview/pengguna-internet-berdasarkan-umur-tahun-20181557988833.

[3] W. Adiansyah, S. Informasi, F. Ilmu, K. Universitas, E. Unggul, T. Tomang, and K. Jeruk, "Membangun Jaringannirkabel ( Hotspot Area ) Dan Manajemen Hotspotdengan ' Antamedia Hotspot Manager ," vol. 10, no. September, pp. 97-119, 2014.

[4] S. Purwana ES, Dedi, Rahmi, Aditya, "Pemanfaatan Digital Marketing Bagi Usaha Mikro, Kecil , Dan Menengah ( Umkm )," J. Pemberdaya. Masy. Madani, vol. 1, no. 1, pp. 1-17, 2017.

[5] P. K. Kannan and H. "Alice" Li, "Digital marketing: A framework, review and research agenda," Int. J. Res. Mark., vol. 34, no. 1, pp. 22-45, 2017.

[6] A. Wardhana, "Strategi Digital Marketing dan Implikasinya Pada Keunggulan Bersaing UMK di Indonesia," Semin. Nas. Keuang. dan Bisnis IV, no. April 2015, pp. 327-337, 2015.

[7] I. Ramadhan and H. Sastramihardja, "Pemanfaatan Web Crawler Dalam Mengumpulkan Informasi Melalui Internet," in Konferensi Nasional Ssistem Informasi, 2018, pp. 8-9.

[8] R. A. Bayu, "Penggunaan Web Crawler Untuk Menghimpun Tweets dengan Metode PreProcessing Text Mining," Infotel, vol. 7, no. 2, pp. 93-100, 2015.

[9] U. Gajah and U. Diponegoro, "Karakteristik Metodologi Penelitian Bidang Ilmu Komputer ( Ik ) Berlandaskan Pendekatai \Positivistik Jazi Eko Istiyanto dan Aris Puji Widodo," J. Sains Mat., vol. 17, no. 2, pp. 115-120, 2009.

[10] I. Sommerville, Software Engineering (10th edition). 2016.

TRANSFORMATIKA Vol. 17, No. 1, July 2019: 41-48 